\title{
Role of gastric acid suppression in the treatment of gastro-oesophageal reflux disease
}

\author{
N J V Bell, R H Hunt
}

\begin{abstract}
Gastro-oesophageal reflux disease is a common condition with a complex pathophysiology. Despite the spectrum of abnormalities, gastric acid has a central role in mucosal damage, and the mainstay of medical treatment is suppression of gastric acid secretion. The results of antisecretory treatment as assessed by endoscopic healing are reviewed. $\mathrm{H}_{2}$ receptor antagonists give more rapid symptom relief than placebo and can produce endoscopic improvement in $31-88 \%$ of cases depending on the severity of oesophagitis. Complete healing, however, is seen only in 27$45 \%$ of patients and these have mainly grades I-II disease. Improved healing rates can be obtained by increasing the degree of acid suppression or the length of treatment. The addition of a prokinetic agent may be beneficial. Omeprazole heals $67-92 \%$ of patients overall and although most successful in the lower grades of oesophagitis, can also heal 48$62 \%$ of patients with grade IV disease. The degree and rate of healing seem to be related to the reduction in oesophageal acid exposure and thus may correlate with the degree and duration of acid suppression over 24 hours obtained by the various treatments. The underlying pathophysiology is unchanged, however, and long term treatment may be needed to maintain remission.
\end{abstract}

Gastro-oesophageal reflux disease (GORD) is a very common condition in the western world with an estimated incidence of $7 \%$ of the adult population. ${ }^{\prime}$ Reflux of gastric or duodenal contents into the oesophagus gives rise to symptoms of heartburn and regurgitation which are the principle reasons for the widespread consumption of antacid preparations. ${ }^{2}$ While most patients with mild GORD present with symptoms of heartburn, in more severe cases reflux of gastric contents results in mucosal inflammation, ulceration, or stricture formation. Furthermore, protracted reflux over many years can result in metaplastic changes and the development of Barrett's epithelium.

The pathophysiology of GORD is complex and not yet fully understood. Defective lower oesophageal sphincter (LOS) motility may be the most important abnormality, of which two main types have been identified. ${ }^{3}$ Transient relaxation of the lower oesophageal sphincter, lasting 5-35 seconds and independent of normal peristalsis, is seen in $60-83 \%$ of reflux episodes, and there is impaired suppression of these periods of sphincter relaxation in the supine position in patients with GORD when compared with healthy controls. Loss of the basal lower oesophageal sphincter tone is thought to account for up to $22 \%$ of reflux episodes especially in the more severe grades of oesophagitis. ${ }^{4}$ Absence of basal LOS tone is rarely continuous but may last up to $\mathbf{1 0}$ minutes. Both forms of LOS dysfunction can occur in the same patient. Once reflux has occurred, impaired clearance of gastric contents from the oesophagus contributes to the exposure of the mucosa to damaging refluxate. Reduced gastric emptying, the presence of hiatus hernia, and impaired mucosal resistance to injury are also implicated in the pathogenesis of GORD.

Despite this spectrum of abnormalities, the role of gastric acid is considered essential to mucosal damage. Indeed, intraoesophageal acid perfusion has been used for diagnosis, as with the Bernstein acid perfusion test, and 24 hour intraoesophageal $\mathrm{pH}$ monitoring has become widely accepted as the standard test to detect reflux.

Thus, the mainstay of medical treatment for GORD has been aimed at eliminating oesophageal acid exposure, either by neutralisation with alkalies or by suppressing gastric acid secretion. The simple measures of weight loss, dietary control, abstinence from smoking, and raising the head of the bed remain important first line recommendations. Raising the bed head by 20 $\mathrm{cm}$ significantly augmented the symptomatic improvement seen with ranitidine from $77 \%$ to $87 \%$ in a group of 71 patients with grade III oesophagitis. ${ }^{5}$

Comparison of the various treatments used in GORD is complicated by the lack of agreed diagnostic criteria for oesophagitis, with some authors relying on symptomatology, radiological findings, or ambulatory $\mathrm{pH}$ monitoring, and others prefering endoscopic, histological, or acid perfusion studies. In order to assess the place of gastric acid suppression in the management of peptic oesophagitis, this paper reviews published studies that have used endoscopic healing as an end point for the evaluation of treatment regimens.

Unfortunately, the endoscopic diagnostic criteria also vary between trials, with several different grading systems used. There is agree-

Division of
Gastroenterology,
McMaster University
Medical Centre,
Hamilton, Ontario,
Canada
N J V Bell
R H Hunt
Correspondence to:
Professor R H Hunt, Division
of Gastroenterology,
McMaster University Medical
Centre, 1200 Main Street
West, Room 4W8, Hamilton,
Ontario L8N 3Z5, Canada.
Accepted for publication
25 March 1991


ment that confluent ulceration or stricture formation represent severe disease, but in lower grades there are considerable differences in the definition and application of criteria. Some authors accept mucosal erythema, oedema, or friability as mild oesophagitis whereas others require the presence of epithelial defects, as in the Savary-Miller classification. ${ }^{6}$ This alone may account for the variability in healing rates between studies.

A further confounding factor is that most trials have allowed free use of antacids in addition to the treatment under investigation.

\section{$\mathrm{H}_{2}$ receptor antagonists}

\section{CIMETIDINE}

Cimetidine has been compared with placebo in 10 trials. $^{7-16}$ These show a trend towards more rapid symptomatic relief compared with placebo groups, which was significant in five of the 10 studies. When endoscopic evaluation was considered, cimetidine produced an improvement in endoscopic grade, although this was significantly better than placebo in only three trials (Table I). Brown found a resolution of endoscopic changes in $55.6 \%$ with placebo against $81.8 \%$ with cimetidine $1 \mathrm{~g}$ per day, however $72 \cdot 7 \%$ of these patients had minimal changes of mucosal friability or exudation at entry to the trial which would not be considered oesophagitis by more stringent criteria. ${ }^{10}$ Cimetidine treated patients consumed significantly less antacid in five of eight studies, and in a randomised crossover trial using a double dummy technique, Petrokubi and Jeffries found a highly significant improvement in endoscopic oesophagitis with cimetidine 300 mg four times daily compared with antacid, with complete healing of mucosal erosions in $47 \%$ taking cimetidine compared with $7 \%$ taking regular antacid. ${ }^{17}$

In a dose ranging study, Kaul et al found no difference in endoscopic improvement with 800 or $1600 \mathrm{mg}$ cimetidine daily or between six and 12 weeks' treatment. $^{18}$ Likewise, twice daily dosage was as effective as a four times a day regimen, with a healing rate of $55 \%$ in 118 patients receiving $1200 \mathrm{mg}$ cimetidine daily. ${ }^{19}$

Cimetidine $300 \mathrm{mg}$ four times daily was as effective as bethanecol $25 \mathrm{mg}$ four times daily, with a six week healing rate of $68.2 \%$ for cimetidine compared with $52.4 \%$ for bethanecol. ${ }^{20}$ Cimetidine also compared favourably with sucralfate in a study that showed an improvement of $67 \%$ for cimetidine $400 \mathrm{mg}$ four times daily compared with $53 \%$ for sucralfate $1 \mathrm{~g}$ four times daily over an eight week period. ${ }^{21}$

\section{RANITIDINE}

In comparisons with placebo, ranitidine was superior in relieving symptoms of nocturnal and daytime heartburn and in reducing antacid consumption..$^{22-30}$ Ranitidine treatment is also associated with a significant improvement in the endoscopic grading of oesophagitis (Table II). When complete resolution of all epithelial defects is evaluated, however, healing occurred in only $33 \%(17-56)$ of ranitidine treated patients compared with $13 \%(3-41)$ with placebo. Goy et al found improvement in $88 \%$ of patients treated with ranitidine $150 \mathrm{mg}$ twice daily, but observed complete healing in only $18 \%$, none of whom had severe oesophagitis at entry to the study. ${ }^{23}$

Johansson et al, in a well designed double blind crossover study, looked at a group of patients who were unresponsive to first line measures including antacids. They found complete healing in $34 \%$ of ranitidine treated patients compared with $3 \%$ on placebo, but all of these were from the group with Savary-Miller grade I oesophagitis or less. ${ }^{26}$ None of the patients with grades II or III disease had complete resolution of the endoscopic findings. The exclusion of patients who improved on first line methods and antacids from the study may partly explain the discrepancy between the findings in this trial and those of Grove $e t a l^{24}$ and Hine $e t a l^{25}$ who found no significant difference between ranitidine and 'antacid placebo.'

In an Italian multicentre study, Bovero et al showed that a bedtime dose of ranitidine $300 \mathrm{mg}$ was as effective as ranitidine $150 \mathrm{mg}$ twice daily, ${ }^{31}$ a finding subsequently confirmed by Halvorsen et al. ${ }^{32}$ Schaub et al found no significant benefit in increasing the dose to $300 \mathrm{mg}$ twice daily, ${ }^{33}$ although a recent study by Johnson has found that increasing the dose of ranitidine from 150 twice daily to $300 \mathrm{mg}$ four times daily improved the healing of Savary-Miller grades IIIII oesophagitis from $29 \%$ to $63 \%$ at four weeks $(\mathrm{p}<0.0001)$ with a further improvement from $54 \%$ to $75 \%$ at eight weeks. ${ }^{34}$

In comparisons with prokinetic agents, ranitidine $150 \mathrm{mg}$ twice daily was shown to be superior to metoclopramide $10 \mathrm{mg}$ three times daily, ${ }^{35}$ and more recently, equivalent to cisapride $10 \mathrm{mg}$ four times daily for Savary-Miller grades I-II oesophagitis. ${ }^{36}$

Ranitidine and cimetidine have been compared directly in only one published study in which the investigators found no difference between ranitidine $150 \mathrm{mg}$ twice daily and cimetidine $400 \mathrm{mg}$ twice daily at eight weeks, although the study was limited to a small number of patients. ${ }^{37}$

\section{FAMOTIDINE}

In an open trial in patients with grades I or II oesophagitis, famotidine $40 \mathrm{mg}$ at night resulted in symptomatic relief in $81 \%$ of patients within four weeks and endoscopic healing in $82 \%$ at 12 weeks. ${ }^{38}$ Berenson et al have recently reported the results of a controlled study of 318 patients with grades II-IV oesophagitis in which famotidine $40 \mathrm{mg}$ twice daily healed $48 \%$ patients at six weeks compared with $18 \%$ with placebo. ${ }^{39}$ These figures increased to $69 \%$ and $29 \%$ respectively at 12 weeks. A lower dose of $20 \mathrm{mg}$ twice daily healed $54 \%$ of patients at 12 weeks but at six weeks was not significantly better than placebo. These results reflect the findings of 24 hour oesophageal pH monitoring. Famotidine $20 \mathrm{mg}$ twice daily was more effective at reducing the total percentage of reflux time than a single $\mathbf{4 0}$ mg dose of famotidine given at bedtime, but only $40 \mathrm{mg}$ twice daily was significantly superior in 
TABLE I Comparison of cimetidine (CIM) and placebo (PLAC) in improvement of endoscopic grade of reflux oesophagitis

\begin{tabular}{|c|c|c|c|c|c|c|}
\hline \multirow[b]{2}{*}{ Author } & \multirow[b]{2}{*}{ Year } & \multirow{2}{*}{$\begin{array}{l}\text { Dose } \\
\text { (mg/day) }\end{array}$} & \multirow[b]{2}{*}{ Weeks } & \multicolumn{2}{|c|}{$\%$ Improved } & \multirow[b]{2}{*}{$p$ value } \\
\hline & & & & $C I M$ & $P L A C$ & \\
\hline Behar $^{7}$ & 1978 & 1200 & 8 & 45 & 37 & NS \\
\hline Breen $^{8}$ & 1983 & 1000 & 8 & 31 & 42 & NS \\
\hline Bright-Asare? & 1980 & 1200 & 8 & 78 & 78 & NS \\
\hline Brown $^{10}$ & 1979 & 1000 & 8 & 82 & 56 & N/A \\
\hline Ferguson" & 1979 & 1600 & 26 & 63 & 31 & $<0.05$ \\
\hline Festen $^{12}$ & 1980 & 1600 & 8 & 46 & 14 & NS \\
\hline Fiasse $^{13}$ & 1980 & 1600 & 8 & 53 & 33 & NS \\
\hline Greaney ${ }^{14}$ & 1981 & 1600 & 6 & N/A & N/A & NS \\
\hline Powell-Jackson ${ }^{15}$ & 1978 & 1600 & 6 & 47 & 40 & NS \\
\hline Wesdorp ${ }^{16}$ & 1978 & 1600 & 8 & 67 & 0 & $<0.01$ \\
\hline
\end{tabular}

TABLE II Comparison of ranitidine (RAN) and placebo (PLAC) in improvement of endoscopic grade of reflux oesophagitis

\begin{tabular}{|c|c|c|c|c|c|c|}
\hline \multirow[b]{2}{*}{ Author } & \multirow[b]{2}{*}{ Year } & \multirow{2}{*}{$\begin{array}{l}\text { Dose } \\
\text { (mg/day) }\end{array}$} & \multirow[b]{2}{*}{ Weeks } & \multicolumn{2}{|c|}{$\%$ Improved } & \multirow[b]{2}{*}{ pvalue } \\
\hline & & & & $R A N$ & PLAC & \\
\hline Berstad $^{22}$ & 1982 & 300 & 6 & 71 & 32 & $<0.01$ \\
\hline Goy $^{23}$ & 1983 & 300 & 6 & 88 & 28 & $<0.01$ \\
\hline Grove $^{24}$ & 1985 & 300 & 6 & N/A & N/A & NS \\
\hline Hine $^{25}$ & 1984 & 300 & 6 & 48 & 25 & NS \\
\hline Johansson $^{26}$ & 1986 & 300 & 8 & 49 & 6 & $<0.01$ \\
\hline Lehtola ${ }^{27}$ & 1986 & 450 & 6 & 60 & 26 & $<0.05$ \\
\hline Sherbaniuk ${ }^{28}$ & 1984 & 300 & 6 & 61 & 48 & $<0.05$ \\
\hline Sontag ${ }^{29}$ & 1987 & 300 & 6 & 63 & 46 & $=0.06$ \\
\hline Wesdorp ${ }^{30}$ & 1983 & 300 & 6 & 79 & 24 & $<0.01$ \\
\hline
\end{tabular}

TABLE III Four week endoscopic complete healing rates for omeprazole $(\mathrm{OH}) \mathrm{v}$ ranitidine $(R A N) 300 \mathrm{mg} /$ day

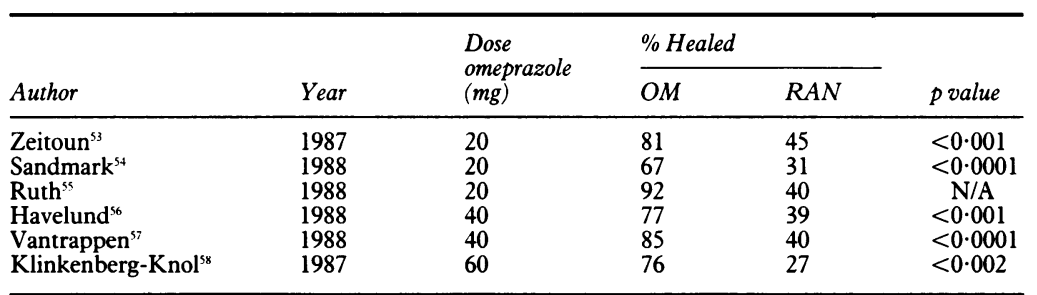

reducing the number of reflux periods longer than five minutes occurring in the upright position. All three treatment regimens successfully decreased the nocturnal percentage of acid contact time, the number of reflux episodes, and the number of episodes lasting more than five minutes in the supine position. ${ }^{+0}$

\section{NIZATIDINE}

Nizatidine has been evaluated in three trials. Twice daily dosage with $150 \mathrm{mg}$ was significantly superior to placebo in reducing endoscopic oesophagitis, but $300 \mathrm{mg}$ given once a day failed to show any significant benefit. ${ }^{+1}$ Similar findings were reported by Quik et al from a study of 325 patients. Nizatidine $300 \mathrm{mg}$ twice daily healed $50 \%$ of the patients at 12 weeks compared with $34 \%$ on placebo, but once daily dosage with 300 mg was not significantly better than placebo. When assessed by entry grade, however, the advantage of twice a day as opposed to a single daily dose was apparent for severe oesophagitis only. ${ }^{+2}$ Berges et al also found that the twice daily dose gave significantly better 12 week healing rates than the once a day regimen. ${ }^{+3}$

The implication in the findings for both of the newer $\mathrm{H}_{2}$ receptor antagonists (famotidine and nizatidine) is that reflux oesophagitis of grades II-IV requires prolonged acid suppression for healing whereas mild disease (grade I) will respond to nocturnal acid inhibition alone.

\section{COMBINATION THERAPY}

In an attempt to improve the healing rates in reflux oesophagitis, the effect of gastric acid suppression with the $\mathrm{H}_{2}$ receptor antagonists in combination with other agents has been studied. Lieberman and Keefe, in a double blind trial, treated 25 patients resistant to cimetidine alone with cimetidine $1200 \mathrm{mg}$ per day in combination with metoclopramide $40 \mathrm{mg}$ per day or placebo. They found that 9 of $12(75 \%)$ patients improved endoscopically as well as symptomatically on combination therapy compared with 4 of 12 $(33 \%)$ treated with cimetidine alone. However, side effects caused by the dopaminergic antagonist action of metoclopramide such as intermittent fatigue and increased anxiety were common. ${ }^{4+}$ Against this, Temple et al reported no benefit from the combination, but found that side effects necessitated withdrawal in one third of the patients. ${ }^{45}$

The newer prokinetic agent cisapride has also been used in combination with $\mathrm{H}_{2}$ antagonists. Cisapride $10 \mathrm{mg}$ twice daily, when given together with ranitidine $150 \mathrm{mg}$ twice daily showed a trend towards improvement over ranitidine 150 mg twice daily alone at 12 weeks, but the difference failed to reach statistical significance. ${ }^{46}$ When combined with cimetidine $1 \mathrm{~g}$ daily, cisapride $40 \mathrm{mg}$ per day improved endoscopic healing at 12 weeks from $46 \%$ to $70 \%$ compared with cimetidine $1 \mathrm{~g}$ per day alone in patients with Savary-Miller grades II or III oesophagitis. ${ }^{47}$ In this small study of 24 patients, there were no serious side effects reported, suggesting that there is a place for a larger controlled trial.

Colloidal bismuth $120 \mathrm{mg}$ four times daily has been used in combination with cimetidine 800 mg at night for severe (Savary-Miller grades IIIIV) oesophagitis. ${ }^{+8}$ Together, they gave significantly better results than cimetidine alone. Seven of the 10 patients on double therapy had complete resolution of their oesophagitis, the other three improving by at least two grades. In comparison, none of the 10 patients treated with cimetidine alone returned to grade 0 during the three weeks of the trial. It is not known whether this action is due to the cytoprotective properties of colloidal bismuth or to its action on Helicobacter pylori, which was found in the oesophagus in 9 of 20 patients.

Sucralfate also acts as a mucosal protective agent. In contrast to colloidal bismuth, however, the combination with cimetidine was not signifcantly different to treatment with sucralfate alone. ${ }^{+9}$

\section{ACID PUMP INHIBITION}

Omeprazole is the first of a new class of drugs that specifically blocks the enzyme $\mathrm{H}^{+} / \mathrm{K}^{+}$. ATPase in the parietal cell, and effectively inhibits gastric acid secretion.

In an open study, Dent showed that $30 \mathrm{mg}$ omeprazole daily could heal oesophageal ulceration in 6 of 8 patients within four weeks and in 7 
of 8 at eight weeks, with the remaining patient having a $95 \%$ reduction in area of ulceration. ${ }^{50}$ When compared with placebo, omeprazole produced healing in $81 \%$ of the patients at four weeks $v 6 \%$ for placebo. Symptomatic improvement was just as impressive with complete relief from all symptoms being achieved in $39 \%$ of patients at only two weeks compared with 3\% in the placebo group. ${ }^{51}$ Hetzel et al went on to compare two different dosages in 164 patients: omeprazole $40 \mathrm{mg}$ resulted in $82 \%$ healing at four weeks in contrast to $70 \%$ with the $20 \mathrm{mg}$ dose. At eight weeks the cumulative healing rates were $85 \%$ and $79 \%$ respectively.

An initial trial comparing omeprazole and ranitidine suggested a significant difference in favour of omeprazole. ${ }^{52}$ These findings have subsequently been confirmed in several studies (Table III). The results for omeprazole are particularly impressive since they represent complete healing, not just improvement, and the study groups included those with severe (grades III-IV) oesophagitis. Not surprisingly, better healing rates were achieved in those with lower grades of disease; $90-100 \%$ of patients with grades I-II oesophagitis healed within four weeks compared with $53-55 \%$ of those treated with ranitidine. ${ }^{56}{ }^{57}$ Even at 12 weeks, the results for ranitidine showed healing in only $88 \%$ for grades I-II. For grade III disease, healing takes slightly longer. Omeprazole achieved $70 \%$ healing at four weeks and $90 \%$ healing at 8 to 12 weeks. Omeprazole is also effective in the treatment of grade IV oesophagitis, with healing observed in $48 \%$ at four weeks increasing to $62 \%$ at eight weeks. ${ }^{5}$

The improved healing rates achieved by omeprazole over the $\mathrm{H}_{2}$ antagonists, seem to be directly related to the greater degree and duration of acid suppression provided by inhibition of the acid pump. Using 24 hour intraoesophageal $\mathrm{pH}$ monitoring, Pasqual showed that omeprazole could reduce reflux, as measured by the time the $\mathrm{pH}$ was below 4 , from mean (SEM) $11 \cdot 2(4.5) \%$ to less than $5 \%$ over the 24 hour period. ${ }^{59}$ Omeprazole $40 \mathrm{mg}$ resulted in a significantly shorter time below pH 4 than $20 \mathrm{mg}$ $(0 \cdot 7(1 \cdot 3) \%$ v $3 \cdot 1(4 \cdot 1) \%)$. Ruth et al compared the effects of ranitidine and omeprazole on oesophageal $\mathrm{pH} .{ }^{55}$ They found that $20 \mathrm{mg}$ omeprazole significantly reduced all reflux variables when analysed according to body position and total values, except for the duration of the longest reflux period which was significantly improved only in the upright position. Ranitidine $150 \mathrm{mg}$ twice daily, however, was only significant in reducing the total reflux time.

In a double blind comparison with cimetidine, omeprazole $40 \mathrm{mg}$ provided complete healing in $71 \%$ of patients at eight weeks compared with $23 \%$ healing on cimetidine $400 \mathrm{mg}$ four times daily. Patients with grades III-IV oesophagitis comprised more than $60 \%$ of both study groups. Twenty four hour oesophageal $\mathrm{pH}$ was recorded in 18 of the 67 patients. Both day and night oesophageal acid exposure, as defined by reduction of the oesophageal $\mathrm{pH}$ to 4 or less, was abolished by omeprazole $40 \mathrm{mg}$ in those patients with healed oesophagitis, whereas 3 of 5 patients healed on cimetidine had daytime acid exposure of greater than $5 \%$. Those patients who failed to heal on omeprazole had no change in their mean night time acid exposure. ${ }^{60}$

Klinkenberg-Knol et al performed ambulatory 24 hour oesophageal $\mathrm{pH}$ monitoring in a small group of patients on $60 \mathrm{mg}$ omeprazole. They found that acid reflux was not entirely abolished by even such high doses of omeprazole. Two of their seven patients had pathologically long supine reflux periods. ${ }^{61}$ This may account for the few patients who fail to heal despite such high dose treatment.

\section{Discussion}

The above studies clearly show that increasing the degree of gastric acid suppression increases the healing of reflux oesophagitis in the short term. This does not, however, alter the natural history of the disease. Relapse is common on stopping treatment, with some $20 \%$ only remaining in remission at six months and approximately $50 \%$ relapsing in under two months. ${ }^{1+5156}$

Maintenance treatment with reduced doses of antisecretory drugs seems to have no advantage over placebo. ${ }^{1862}$ Sherbaniuk, however, found that longterm treatment with full dose ranitidine could maintain the improvements obtained over one year. ${ }^{28}$ Omeprazole 10 or $20 \mathrm{mg}$ once daily has been used for maintenance therapy and at 20 mg daily reduces the relapse rate to $20 \%$ at one year. Weekend only dosage regimens have been studied but have not proved to be of benefit. ${ }^{6364}$

The disappointing results obtained by the $\mathrm{H}_{2}$ receptor antagonists may be partly explained by the pathophysiology of the condition. Johansson and Tibbling performed gastric secretion tests and 24 hour $\mathrm{pH}$ monitoring in a group of 42 patients with reflux oesophagitis. ${ }^{65}$ They found gastric hypersecretion in $76 \%$, and that basal and peak acid output, number of reflux episodes, and total supine reflux time were significantly more reduced in symptomatic responders than in nonresponders. The basal acid output has also been shown to correlate with the severity of reflux disease; patients with erosive oesophagitis and Barrett's oesophagus have significantly higher basal acid outputs than those with heartburn alone. ${ }^{66}$ Serum gastrin values are also higher in resistant cases. ${ }^{67}$

Collen $e t$ al have recently published a study of patients resistant to conventional doses of ranitidine. ${ }^{68}$ The non-responders had significantly higher basal acid outputs than those who experienced complete symptomatic relief, and 9 of 12 were true hypersecretors (basal acid output $>10$ $\mathrm{mEq} /$ hour). Symptomatic relief was achieved in 10 of 12 using increased doses of ranitidine (up to $1800 \mathrm{mg} /$ day). They found that basal acid output had to be almost completely suppressed (to below $1 \mathrm{mEq} /$ hour) for heartburn to be relieved. The longest period of unbuffered basal acid output occurs at night, and studies have shown that the degree of supine reflux correlates with the severity of oesophagitis to a greater extent than day time reflux. ${ }^{69}$ This may reflect the impaired clearance of acid from the oesophagus and diminished neutralisation by salivary bicarbonate at night, as well as the potency of the refluxate. The healing rates of the various drugs 
seem to reflect their ability to inhibit gastric acid production, as has been shown for duodenal and gastric ulcer disease. ${ }^{7071} \mathrm{~A}$ recent meta-analysis has shown that duodenal ulcer healing not only correlates with the degree of acid suppression but also with the duration of acid suppression and the length of treatment. ${ }^{72}$ Furthermore, there is no benefit from increasing the suppression to above a gastric $\mathrm{pH}$ of $3 \cdot 0$, but increasing the duration of the antisecretory effect is more important. As oesophageal reflux can occur throughout the whole 24 hours, a similar relation to that seen for duodenal ulcer disease may exist. The ability of omeprazole to achieve a longer duration of acid suppression presumably accounts for its success in treating oesophagitis resistant to $\mathrm{H}_{2}$ receptor blockade.

As stated previously, GORD is a multifactorial condition. The presence of a competent lower oesophageal sphincter mechanism is important. Leiberman found oesophageal sphincter pressures to be lower in his group of relapsing patients than in those in prolonged remission. ${ }^{73}$ Although LOS hypotonia can be induced by peptic oesophagitis, healing of oesophagitis with antisecretory agents fails to improve LOS motility ${ }^{50}$ and relapse is the rule on withdrawal of treatment. The addition of cisapride may well allow a bimodal approach to therapy.

In contrast to most pharmacological treatments, the surgical approach to GORD has been aimed at improving LOS function. Anti-reflux surgery has been directly compared with medical treatment in three trials. Behar, before the advent of the $\mathrm{H}_{2}$ antagonists, reported an excellent result in $73 \%$ of patients after fundoplication, with a minimum follow up of 20 months. In contrast, only $19 \%$ of those maintained on antacids had a satisfactory response. ${ }^{74}$ Posterior partial $\left(270^{\circ}\right)$ fundoplication has been compared with long term treatment with ranitidine $150 \mathrm{mg}$ twice daily. ${ }^{75}$ Initial eight week treatment with ranitidine produced some improvement, but no further benefit was obtained from extending treatment to six months. After surgery, performed in a group showing no improvement with ranitidine, all patients had a normal endoscopic appearance at six months. Only 1 of 15 patients experienced mild symptoms involving an inability to belch, a relatively common problem after a $360^{\circ}$ Nissan procedure. Spechler $e t$ al have shown that the improved results of surgery over medical treatment with ranitidine are maintained at one year's follow up. ${ }^{76}$

Long term profound acid suppression with either high dose $\mathrm{H}_{2}$ receptor antagonists or with omeprazole may be necessary to obtain lasting symptomatic relief and endoscopic healing equivalent to that obtained surgically, especially for grades III and IV ulcerative oesophagitis. The safety of such a life time of acid suppression is uncertain, although 15 years post marketing surveillance of cimetidine has proved it to be remarkably safe and omeprazole has been used compassionately for up to six years without significant adverse effect. ${ }^{77}$ While enterochromaffin like cell hyperplasia and gastric carcinoid formation have been reported in rats given long term high dose omeprazole, these changes have since been shown to occur with $\mathrm{H}_{2}$ receptor antagonists such as ranitidine and loxtidine, the hypolipidaemic compound ciprofibrate or after partial fundectomy. ${ }^{78-80}$ This phenomenom seems to be due to the hypergastrinaemia associated with acid suppression achieved by a variety of means, rather than a direct effect of any of the agents, and furthermore is reversible by antrectomy ${ }^{81}{ }^{82}$ Prolonged hypochlorhydria, however, may predispose to late gastric carcinoma as observed some 20 years after surgery for benign peptic ulcer disease. ${ }^{83}{ }^{84}$ Experimentally, at least, operations resulting in duodenogastric bile reflux increase the susceptibility of the gastric mucosa to neoplastic change.$^{85}$ It is thought that a high intragastric $\mathrm{pH}$ promotes bacterial overgrowth which converts dietary nitrates and nitrites into carcinogenic $N$-nitroso compounds. Bile reflux seems to be involved in carcinogenesis, but whether by the formation of cocarcinogens or as a promoter by increasing mucosal permeability to initiating carcinogens is uncertain..$^{86}$ Until these matters are resolved, particularly for the younger patient, there remains a role for surgery in the management of GORD.

1 Nebel OT, Forbes MF, Castell DO. Symptomatic gastroesophageal reflux: Incidence and precipitating factors. $A m \mathcal{F}$ Dig Dis 1976; 21: 953-6.

2 Graham DY, Smith JL, Patterson DJ. Why do apparently healthy people use antacid tablets? Am $\mathcal{F}$ Gastroenterol 1983; 78: $257-60$.

3 Dent J. Recent views on the pathogenesis of gastrooesophageal reflux disease. In: Tytgat GNJ, ed. Baillère's oesophageal reflux disease. In: Tytgat GNJ, ed. Baillère's Clinical Gas

4 Dent J, Dodds WJ, Toouli J, Barnes B, Lewis I. Mechanisms of sphincter incompetence in patients with symptomatic gastro-oesophageal reflux. Gastroenterology 1983; 84: 1135 .

5 Harvey RF, Gordon PC, Hadley N, et al. Effects of sleeping with the bed-head raised and of ranitidine in patients with severe peptic oesophagitis. Lancet 1987; ii: 1200-3.

6 Savary M, Miller G. In: Savary M, Miller G, eds. The esophagus. Handbook and atlas of endoscopy. Solothurn, esophagus. Handbook and atlas of endoscopy. So

7 Behar J, Brand DL, Brown FC, et al. Cimetidine in the treatment of symptomatic gastroesophageal reflux. Gastroenterology 1978; 74: 441-8.

8 Breen KJ, Desmond PV, Whelan G. A randomized, controlled evaluation of cimetidine. Med $\mathcal{F}$ A ust 1983; 2: 555-6.

9 Bright-Asare P, El-Bassoussi M. Cimetidine, metoclopramide, or placebo in the treatment of symptomatic gastro-
esophageal reflux. F Clin Gastroenterol $1980 ; 2: 149-56$.

10 Brown P. Cimetidine in the treatment of reflux oesophagitis. Med $\mathcal{F}$ Aust 1979; 2: 96-7.

11 Ferguson R, Dronfield MW, Atkinson M. Cimetidine in the treatment of reflux oesophagitis with peptic stricture. $B M \mathcal{F}$ 1979; 2: 472-4.

12 Festen HPM, Driessen WMM, Lamers CBH, Van Tongeren JHM. Cimetidine in the treatment of severe ulcerative reflux oesophagitis; results of an 8-week double-blind study and of subsequent long-term maintenance treatment. Neth $\mathcal{F} \mathrm{Med}$ 1980; 23: $237-40$

13 Fiasse R, Hanin C, Lepot A, Descamps C, Lamy F, Dive C. Controlled trial of cimetidine in reflux esophagitis. Dig Di Sci 1980; 25: 750-5.

14 Greaney MG, Irvin TT. Cimetidine for the treatment of symptomatic gastro-oesophageal reflux. $\mathrm{Br} \mathcal{F}$ Clin Pract 1981; 35: 21-4.

15 Powell-Jackson P, Barkley $H$, Northfield TC. Effect of cimetidine in symptomatic gastro-oesophageal reflux. Lancet 1978; ii: 1068-9.

16 Wesdorp E, Bartelsman J, Pape K, Dekker W, Tytgat GN. Oral cimetidine in reflux esophagitis: a double blind control led trial. Gastroenterology 1978; 74: 821-4.

17 Petrokubi RJ, Jeffries GH. Cimetidine versus antacid in scleroderma with reflux esophagitis. Gastroenterology 1979; 77: 691-5.

18 Kaul B, Petersen H, Erichsen $\mathrm{H}$, et al. Acute and maintenance treatments with cimetidine. Scand $\mathcal{F}$ Gastroenterol 1986; 21 : $139-45$.

19 Archambault AP, Farley A, Cleator IG, et al. Cimetidine therapy for gastroesophageal reflux disease. West $\mathcal{f}$ Med 1985; 143: 616-21.

20 Thanik K, Chey WY, Shak A, Hamilton D, Nadelson N. Bethanecol or cimetidine in the treatment of symptomatic reflux esophagitis. Arch Intern Med 1982; 142: 1479-81. 
21 Hameeteman W, v d Boomgaard DM, Dekker W, Schrijver $M$, Wesdorp ICE, Tytgat GNJ. Sucralfate versus cimetidine in reflux esophagitis. $\mathcal{f}$ Clin Gastroenterol 1987; 9: 390-4.

22 Berstad A. Overview of ranitidine in reflux oesophagitis: its effect on symptoms, endoscopic appearance and histology. In: Misiewicz JJ, Wormsley KG, eds. The clinical use of ranitidine. Oxford: Medicine Publishing Foundation, 1982: 297-304.

23 Goy JA, Maynard JH, McNauton WM, O'Shea A. Ranitidine and placebo in the treatment of reflux oesophagitis. Med $\mathcal{F}$ A ust 1983; 2: 558-61.

24 Grove O, Bekker C, Jeppe-Hansen MG, et al. Ranitidine and high dose antacid in reflux oesophagitis. A randomized placebo-controlled trial. Scand F Gastroenterol 1985; 20: 457-61.

25 Hine KR, Holmes GKT, Melikian V, Lucey M, Fairclough PD. Ranitidine in reflux oesophagitis. Digestion 1984; 29: 119-23.

26 Johansson KE, Boeryd B, Johansson K, Tibbling L. Doubleblind crossover study of ranitidine and placebo in gastrooesophageal reflux disease. Scand $\mathcal{F}$ Gastroenterol 1986; 21 : 769-78.

27 Lehtola J, Niemelä S, Martikainen J, Krekelä I. Ranitidine, $150 \mathrm{mg}$ three times a day, in the treatment of reflux oesophagitis. A placebo-controlled, double-blind study. Scand F Gastroenterol 1986; 21: 175-80.

28 Sherbaniuk R, Wensel R, Bailey R, et al. Ranitidine in the treatment of symptomatic gastroesophageal reflux disease. $\exists$ Clin Gastroenterol 1984; 6: 9-15.

29 Sontag S, Robinson M, McCallum RW, Barwick KW, Nardi $R$. Ranitidine therapy for gastroesophageal reflux disease. Results of a large double-blind trial. Arch Intern Med 1987; 147: $1485-91$

30 Wesdorp ICE, Dekker W, Klinkenberg-Knol EC. Treatment of reflux oesophagitis with ranitidine. Gut 1983; 24: 921-4.

31 Bovero E, Cheli R, Barbara L, et al. Short-term treatment of reflux oesophagitis with ranitidine $300 \mathrm{mg}$ nocte, Italian multicentre study. Hepatogastroenterology 1987; 34: 155-9.

32 Halvorsen L, Lee FI, Wesdorp ICE, Johnson NJ, Mills JG, Wood JR. Acute treatment of reflux oesophagitis: a multicentre study to compare $150 \mathrm{mg}$ ranitidine twice daily with $300 \mathrm{mg}$ ranitidine at bedtime. Aliment Pharmacol Therap 1989; 3: 171-81.

33 Schaub N, Meyrick Thomas J, Misiewicz JJ, Lovell D, Trotman IF. Investigation of ranitidine $150 \mathrm{mg}$ bd or $300 \mathrm{mg}$ bd in the treatment of reflux disease. Hepatogastroenterology 1986; 33: 208-13.

34 Johnson NJ, Mills JG, Wood JR. Acute treatment of reflux mg bid with ranitidine $300 \mathrm{mg}$ qid. Gastroenterology 1989; 96: A242.

35 Guslandi M, Testoni PA, Passaretti S, et al. Ranitidine vs metoclopramide in the medical treatment of reflux esophagitis. Hepatogastroenterology 1983; 30: 96-8.

36 Janisch HD, Hüttemann W, Bouzo MH. Cisapride versus ranitidine in the treatment of reflux esophagitis. Hepatogastroenterology 1988; 35: 125-7.

37 Fielding JF, Doyle GD. Comparison between ranitidine and cimetidine in the treatment of reflux oesophagitis. Ir Med $\mathcal{F}$ 1984; 77: 356-7.

38 Sekiguchi $\mathrm{T}$, Nishioka $\mathrm{T}$, Kogure $M$, et al. Once daily famotidine for reflux esophagitis. Scand $\mathcal{f}$ Gastroenterol 1987; 22 (suppl 134): 51-4.

39 Berenson $M$, Simon TJ, Berlin RG, et al. BID regimens of an $\mathrm{H} 2$ receptor antagonist heal erosive esophagitis: results of a US double-blind, randomised multicenter trial. Gastroenterology 1990; 98: A372.

40 Orr WC, Robinson MG, Humphries TJ, Antonello J, Cagliola A. Dose-response effect of famotidine on patterns of gastrooesophageal reflux. Aliment Pharmacol Therap 1988; 2: 22935.

41 Cloud $M$, Offen W. Nizatidine $150 \mathrm{mg}$ bid relieves symptoms and decreases severity of esophagitis in gastro-oesophageal reflux disease. Gastroenterology 1989; 96: A91.

42 Quik RPF, Cooper MJ, Gleeson M, et al. A comparison of two doses of nizatidine versus placebo in the treatment of reflux

43 Berges W, Lux G, Simon B, Weinbeck M, Quik R. A comparison of two doses of nizatidine in reflux oesophagitis. Z Gastroenterol 1989; 27: 156.

44 Lieberman DA, Keefe EB. Treatment of severe reflux esophagitis with cimetidine and metoclopramide. Ann Intern Med
$1986 ; 104: 21-6$.

45 Temple JG, Bradby GVH, O'Connor F, et al. Cimetidine and metoclopramide in oesophageal reflux disease. $B M \mathcal{F} 1983$; 286: 1863-4.

46 Wienbeck $M$. Does cisapride added to $\mathrm{H}_{2}$-receptor-blocking treatment improve healing rates in patients with esophagitis? Digestion 1986; 34: 144 .

47 Galmiche JP, Brandstätter G, Evreux M, et al. Combination therapy with cisapride and cimetidine in severe reflux oesophagitis: a double blind controlled trial. Gut 1988; 29: 675-81.

48 Borkent MV, Beker JA. Treatment of ulcerative reflux oesophagitis with colloidal bismuth subcitrate in combination with cimetidine. Gut 1988; 29: 385-9.

49 Schotborgh RH, Hameeteman W, Dekker W, et al. Combination therapy of sucralfate and cimetidine, compared with sucralfate monotherapy, in patients with peptic reflux esophagitis. Am ₹ Med 1989; 86 (suppl 6A): 77-80.

50 Dent J, Downton J, Buckle P, et al. Omeprazole heals esophagitis by elevation of intragastric $\mathrm{pH}$. Gastroenterology 1985; 88: 1363.

51 Hetzel DJ, Dent J, Reed WD, et al. Healing and relapse of severe peptic esophagitis after treatment with omeprazole. Gastroenterology 1988; 95: 903-12.

52 Dammann HG, Blum AL, Lux G, et al. Omeprazole is superior to ranitidine in the treatment of reflux esophagitis. Gastroenterology 1986; 90: 1385.

53 Zeitoun P, Desjars de Keranroué N, Isal JP. Omeprazole versus ranitidine in erosive oesophagitis. Lancet 1987; ii: 621-22.

54 Sandmark S, Carlsson R, Fausa O, Lundell L. Omeprazole or ranitidine in the treatment of reflux esophagitis. Scand $\mathcal{f}$ Gastroenterol 1988; 23: 625-32.

55 Ruth $M$, Enbom H, Lundell H, Lönroth H, Sandberg N, Sandmark S. The effect of omeprazole or ranitidine treatment on 24-hour oesophageal acidity in patients with reflux esophagitis. Scand F Gastroenterol 1988; 23: 1141-6.

56 Havelund T, Laursen LS, Skoubo-Kristensen E, et al. Omeprazole and ranitidine in treatment of reflux oesophagitis: a double blind comparative trial. $B M \mathcal{F}$ 1988; 296: 8992 .

57 Vantrappen G, Rutgeerts L, Schurmans P, Coenegrachts J-L. Omeprazole $(40 \mathrm{mg})$ is superior to ranitidine in short-term treatment of ulcerative reflux esophagitis. Dig Dis Sci 1988 33: 523-9.

58 Klinkenberg-Knol EC, Jansen JMBJ, Festen HPM, Meuwissen SGM, Lamers CBHW. Double-blind multicentre comparison of omeprazole and ranitidine in the treatment of reflux oesophagitis. Lancet 1987; i: 349-51.

59 Pasqual JC, Hémery P, Bruley S, Galmiche JP. Comparison of the effects of two doses of omeprazole on 24-hour oesophageal $\mathrm{pH}$ in gastroesophageal reflux disease. Gastroenterology 1987; 92: 1567 .

60 Dehn TCB, Shepherd HA, Colin-Jones, Kettlewell MGW, Carroll NJH. Double blind comparison of omeprazole (40 $\mathrm{mg} \mathrm{od}$ ) versus cimetidine ( $400 \mathrm{mg} \mathrm{qd}$ ) in the treatment of symptomatic erosive reflux oesophagitis, assessed endoscopically, histologically and by $24 \mathrm{~h} \mathrm{pH}$ monitoring. Gut 1990; 31: 509-13.

61 Klinkenberg-Knol EC, Festen HPM, Meuwissen SGM. The effects of omeprazole and ranitidine on 24-hour $\mathrm{pH}$ in the distal oesophagus of patients with reflux oesophagitis. Aliment Pharmacol Therap 1988; 2: 221-7.

62 Bright-Asare P, Behar J, Brand DL, et al. Effects of long term maintenance therapy on gastroesophageal reflux disease. Gastroenterology 1982; 82: 1025.

63 Bardhan KD, Daly MJ, Singh S, Morris P, Thompson M, Hinchliffe RFC. Refractory erosive oesophagitis: results of maintenance treatment with high dose $\mathrm{H}_{2}$ receptor antagonists or omeprazole. Gut 1990; 31: A602.

64 Isal JP, Zeitoun P, Barbier P, Cayphas JP, Carlsson R. Comparison of two dosage regimens of omeprazole $-10 \mathrm{mg}$ once daily and $20 \mathrm{mg}$ weekends - as prophylaxis against recurrence of reflux esophagitis. Gastroenterology 1990; 98: A367.

65 Johansson KE, Tibbling L. Gastric secretion and reflux pattern in reflux oesophagitis before and during ranitidine pattern in reflux oesophagitis before and during
treatment. Scand f Gastroenterol 1986; 21: 487-92.

66 Collen MJ, Gallagher JE. Basal acid output and gastric acid hypersecretion in patients with gastroesophageal reflux disease. Gastroenterology 1990; 98: A32.

67 Robertson DAF, Aldersley MA, Shepherd H, Lloyd RS, Smith $\mathrm{CL} . \mathrm{H}_{2}$ antagonists in the treatment of reflux Gut 1987; 28: 946-9.

68 Collen MJ, Lewis JH, Benjamin SB. Gastric hypersecretion in refractory gastroesophageal reflux disease. Gastroenterology

69 Jenkinson LR, Norris TL, Barlow AP, Watson A. Acid reflux and oesophagitis - day or night? Gullet 1990; 1: 36-44.

70 Jones DB, Howden CW, Burget DW, Kerr GD, Hunt RH. Acid suppression in duodenal ulcer: a meta-analysis to define optimal

71 Howden CW, Hunt RH. The relationship between suppression of acidity and gastric ulcer healing. Aliment Pharmacol Therap 1990; 4: 25-34.

72 Burget DW, Chiverton SG, Hunt RH. Is there an optimal degree of acid suppression in healing duodenal ulcer? A model of the relationship between ulcer healing and acid suppression. Gastroenterology 1990; 99: 345-51.

73 Lieberman DA. Medical therapy for chronic reflux esophagitis. Arch Intern Med 1987; 147: 1717-20.

74 Behar J, Sheahan DG, Biancani P, Spiro HM, Storer EH Medical and surgical management of reflux esophagitis. NEnglf Med 1975; 293: 263-8.

75 Johansson KE, Tibbling L. Maintenance treatment with ranitidine compared with fundoplication in gastrooesophageal reflux disease. Scand $\mathcal{F}$ Gastroenterol 1986; 21 : 779-88.

76 Spechler SJ, Williford WO. A prospective, randomized trial of medical and surgical therapies for gastroesophageal reflux disease (GERD). Gastroenterology 1990; 98: A370.

77 Sölvell L. The clinical safety of omeprazole. Scand $\mathfrak{f}$ Gastroenterol 1989; 24 (suppl 166): 106-10.

78 Carlsson E. A review of long-term acid inhibition in animals. Scand F Gastroenterol 1989; 24 (suppl 166): 19-23.

79 Havu N, Mattsson H, Ekman L, Carlsson E. Enterochromaffin-like cell carcinoids in the rat gastric mucosa 
following long-term administration of ranitidine. Digestion 1990; 45: 189-95.

80 Ryberg B, Carlsson E, Carlsson K, et al. Effects of partial resection of acid-secreting mucosa on plasma gastrin and enterochromaffin-like cells in the rat stomach. Digestion 102-8.

81 Larsson H, Carlsson E, Håkanson R, et al. Time-course of development and reversal of gastric endocrine cell hyperplasia after inhibition of acid secretion. Gastroenterology 1988; 95: 1477-86.

82 Ryberg B, Tielmans Y, Axelson J, et al. Gastrin controls ECL cell and stem cell proliferation rate in the rat stomach. In: Abstracts of the World Congress of Gastroenterology. Sydney Abstracts of the World Congress of Gastroenterology. Sydney
1990. Abingdon: The Medicine Group (UK) Ltd, 1990: 444.
83 Caygill CPJ, Hill MJ, Kirkham JS, Northfield TC. Mortality from gastric cancer following gastric surgery for peptic ulcer. Lancet 1986; i: 929-31.

84 Offerhaus GJA, Tersmette AC, Huibregtse K, et al. Mortality caused by stomach cancer after remote partial gastrectomy for benign conditions: 40 years of follow up of an Amsterdam cohort of 2633 postgastrectomy patients. Gut 1988; 29: 1588-90.

85 Sano C, Kumashiro R, Saito T, Inokuchi K. Promoting effect of partial gastrectomy on carcinogenesis in the remnant stomach of rats after oral administration of N-Methyl-NNitro-N-Nitrosoguanidine. Oncology 1984; 41: 124-8.

86 Northfield TC, Hall CN. Carcinoma of the gastric stump: risks and pathogenesis. Gut 1990; 31: 1217-9. 